\title{
Soil-Reclamation Studies of Salt-Affected and Solonetzic Soils in Ukraine*
}

\author{
I. N. Lyubimova \\ Dokuchaev Soil Science Institute, per. Pyzhevskii 7, Moscow, 119017 Russia \\ E-mail: lubimova@agro.geonet.ru \\ Received October 7, 2010
}

DOI: $10.1134 / \mathrm{S} 1064229311080096$

In 2009, a book by A.V. Novikova, one of the most famous Ukrainian soil scientists in the field of ameliorative soil science, was published. It is the collected scientific works of Anna Vasil'evna, which completely characterize her scientific interests. The collection includes five monographs published in 1958-2007 and a number of articles. They are arranged into six parts according to their subjects. A list of the main published works by Novikova is given in the monograph.

The first part of the monograph is entitled The History of the Science. It comprehensively characterizes the history of soil-ameliorative and environmental investigations of saline and solonetzic soils in Ukraine in 1890-1996. The memoirs of the author about her contacts with some Russian soil scientists-S.A. Zakharov, V.A. Kovda, D.G. Vilenskii, I.N. Antipov-Karataev, A.N. Sokolovskii, and A. M. Mozheiko-are also given.

The second part is devoted to the processes of salt accumulation and solonetzization of soils on the steppe part of the Crimea Peninsular. This part includes an article by Novikova Geokhimicheskie $i$ rezhimnye zakonomernosti solenakopleniya v stepnom Krymu (Geochemical and Regime Regularities of Salt Accumulation in the Steppe Crimea) (articles of the Khar'kov Agricultural Institute, 1962, vol. 39, p. 242334). This was the first work that comprehensively studied the features of salt accumulation in different parts of the steppe Crimea. The performed investigations were used as a basis for the zoning of the studied area. The author specified the areas at different stages of salt accumulation, the regions with different intensities of salinization-desalinization, and the zones with different chemical compositions. Measures to reduce the solonetzic properties of these soils are pro-

\footnotetext{
* A. V. Novikova, Issledovaniya zasolennykh i solontsovykh pochv: genesis, melioratsiya, ekologiya (Investigation of Saline and Solonetzic Soils: Genesis, Amelioration, and Ecology), Khar'kov, 2009.
}

posed. The second part is concluded by the article Otsenka vliyaniya impulverizatsii solei na osolontsevanie pochv Prichernomor'ya (Assessment of the Effect of Salt Input from the Sea on the Solonetzic Soil Features of the Black Sea Region) (Pochvovedenie, 2009, no. 12 , pp. 1421-1431).

The third part is devoted to the indication of soil solonetzic manifestations by the illuviation rate. In addition to the calculation approach for assessing the illuviation rate, ranges of the soil solonetzicity in the southern part of the Ukraine indicated by this characteristic are given. The data on the changes in the textural differentiation of the solonetz profile at the transformation of the steppe solonetzes into zonal soils are also interesting.

In the fourth part, methods of amelioration and cultivation of steppe and meadow-steppe solonetzic soils of the Crimea are described along with those for the irrigated dark chestnut solonetzic soils of the Sivash Lake region in the Crimea.

The fifth part presents the conceptual aspects of the prediction of secondary salinization, the leaching of salts, and soda accumulation in irrigated and rain-fed soils in the southern part of the Ukraine.

The last part of the book is based on foreign published issues concerning saline soils. It gives information on the saline soils of the world, their distribution pattern, and cultivation. Ecological problems at the reclamation of these soils are analyzed.

The monograph shows that the solonetzes of the southern part of the Ukraine are very interesting for the author, who has studied them comprehensively. This book will be no doubt interesting and useful for scientists who solve problems of the genesis and amelioration of solonetzes and who will perform investigations in the Ukraine and in other regions where these soils occur. 